\title{
ANGLO-SOVIET RELATIONS IN THE CONTEXT OF THE BALTIC PROBLEM, 1918-1922
}

\author{
Evgeny Sergeev \\ (Institute of World History (Russian Academy of Sciences); \\ Russian State University)
}

ABSTRACT The paper deals with the main trends in relations between Great Britain and Soviet Russia in the context of the 'Baltic problem', which emerged on the international agenda right after the collapse of the Russian Empire, in the process of the Bolsheviks assuming power and conducting a war against the Whites, the troops of the Entente, and the armies of the new independent states. The author focuses on subsequent stages in the decision-making process, and actual steps taken by London and Moscow with regard to the three new east Baltic states of Estonia, Latvia and Lithuania, taking the latter as a special case. In conclusion, a transition can be traced from the first attempts by Britain to guarantee mere self-governing status for the countries in question, to full recognition of their independence, supported by the Bolshevik government, which, however, opposed the emergence of the Baltic League (or Federation) under the indirect patronage of Britain supported by the League of Nations.

KEYWORDS: Soviet Russia; Great Britain; Baltic; Lithuania; World War I; interwar; diplomacy.

\section{Introduction}

There are not many questions in European history that have aroused such intense debates among historians as the Baltic problem in the 20th century. On the eve of the First World War, the territories of the three future Baltic States, Estonia, Latvia and Lithuania, were divided between the Russian and German Empires, though the Russians governed approximately 90 per cent of the east Baltic basin.

It is worth bearing in mind that the declaration of 1908 that was concluded by Russia, Germany, Denmark and Sweden regulated the general status of the Baltic region before the beginning of the Great War. Having abstained from signing this multilateral act of international law, Britain nevertheless approved of it officially, and 
informed the underwriting states of its determination to fully support the compromised principles. However, on one hand, the war put an end to these regulations, while on the other, the Bolshevik policy of instigating socialist revolution all over Europe jeopardised the international order in the Baltic area. Besides, the great powers, including Britain, faced unprecedented challenges regarding the sovereignty of former Russian provinces in the Baltic. The modifications mentioned would inevitably lead to an epochal transformation of the balance of power, not just on a regional basis, but also on a pan-European scale.

What role did the Baltic region play in the course of Anglo-Soviet relations in these turbulent times of wars and revolutions? What were the main interests of London and Moscow in the east Baltic? How did the attitudes of Britain and Russia to the east Baltic states, especially to Lithuania, affect both British and Soviet policy in the period under consideration? And finally, what were the results of the approaches taken by Whitehall and the Kremlin to the Baltic problem in the aftermath of the Russian Revolution?

To discuss these topics and maintain the author's evaluation of the multi-level Baltic problem in the context of the post-First World War settlement, which was complicated, however, by armed clashes of various intensities during the crucial period of 1918 to 1922, we should also take into consideration the fact that the question seems far from being a study of pure academic interest. It allows not only specialists in contemporary history, but also career diplomats and the general public, to appreciate European events in a comparative sense, i.e. in the appraisal of the international situation typical of the east Baltic region through the 20th century.

Regrettably, academic issues on the subject still lack a comprehensive, unbiased appreciation of the Baltic problem as a whole, and the role it played in Anglo-Soviet relations. Numerous lacunas in the fabric of historical narration are due to scholars' limited admission to archives, especially those classified by the authorities. Another obstacle is the deficiency of a non-ideological, strictly objective approach to the study of this highly controversial period in the foreign affairs of the Baltic region. ${ }^{1}$

${ }^{1}$ For the most interesting non-Russian studies, see: A. Dennis, The Foreign Policy of Soviet Russia (London, 1924), pp. 124-140; E. Anderson, 'British Policy toward the Baltic States, 1918-1920', Journal of Central European Affairs, vol. XIX, 3 (1959), pp. 276-289; S. Page, The Formation of the Baltic States. A Study of 
Based on archival records, published diplomatic sources and recollections of witnesses, this paper can be divided into three sections, with the focus, firstly, on an assessment of British and Soviet motives in the east Baltic; secondly, on an evaluation of the changing attitudes of London and Moscow to Lithuania as a case study; and, finally, on a reflection of this process in the attempts to establish an alliance of east Baltic states, including Poland and Finland.

\section{The motives of Great Britain and Soviet Russia in the Baltic}

Although the east Baltic states obviously differ in ethnic, religious and economic respects, they all belong to a unique geo-strategic region stretching along the shores of a sea which separates Finland, Poland, Sweden, Russia and Germany. It is small wonder, therefore, that the development of Estonia, Latvia and Lithuania was often affected, or even moulded, by the more powerful neighbouring countries, especially in modern and contemporary times.

The stalemate on the front caused by the Russian Revolution of 1917, and the virtual collapse of the Italian army at Caporetto in the autumn of that year, compelled David Lloyd George, the head of the British coalition government, to announce the aims of

the Effects of Great Power Politics upon the Emergence of Lithuania, Latvia, and Estonia (Cambridge, Mass., 1959); R. Ullman, Anglo-Soviet Relations 1917-1921, vol. 1 (London, 1961), pp. 51-8; G. von Rauch, Geschichte der baltischen Staaten (Stuttgart, 1970); O. Hovi, The Baltic Area in British Policy 1918-1921, vol. 1 (Helsinki, 1980); The Baltic States in Peace and War, 1917-1945, ed. V.S. Vardys et al. (University Park-London, 1978); The Baltic in International Relations between the Two World Wars, eds. J. Hiden, A. Loit (Stockholm, 1988); R. Debo, Survival and Consolidation: The Foreign Policy of Soviet Russia 1918-1921 (Montreal, etc., 1992), pp. 85-105, 119-146; D. Kirby, The Baltic World, 1772-1993: Europe's Northern Periphery in the Age of Change (London-New York, 1995); Locarno Revisited: European Diplomacy, 1920-1929, ed. G. Johnson (London, 2004); Z. Steiner, The Lights that Failed: European International History 1919-1933 (Oxford, 2005), esp. pp. 256-313.

Recent publications in Russian include: П. Варес, О. Осипова, Похищение Eвропы, или, Балтийский вопрос в международных отношениях ХХ века (Tallinn, 1992); Россия и Балтия, ред. Е. Л. Назарова (Москва, 2002); В. А. Зубачевский, 'Политика России в отношении восточной части Центральной Европы. 1912-1921', Вопросы истории, по. 9 (2009), pp. 100-9; Россия и Латвия в потоке истории: 2-я половина XIX - 1-я половина XX в., ред. Е.Л. Назарова (Москва, 2015). 
the Entente, and Britain as the leading member of the Alliance, to delegates at the Trade Unions' Conference on 5 January 1918. Touching on relations with Russia, the Prime Minister mentioned only Poland as a country deserving sovereignty, without specifying the future status of the Baltic territories of the former Romanov Empire. ${ }^{2}$ Hence, we might conclude that any hope of independence for the Estonians, Latvians or Lithuanians was out of the question for Whitehall at that time. The British government aimed at the complete defeat of Germany at any cost, and it was of primary importance to London to keep the Eastern Front going, in spite of the negotiations in progress at Brest-Litovsk between the Soviets and the Quadruple Alliance in early 1918. Typically, Arthur Balfour, the Foreign Secretary, instructed Francis Lindley, then Chargé d'Affaires in Petrograd: 'Internal affairs in Russia are no concern of ours, and we only consider them in so far as they affect the war.' ${ }^{3}$

The conclusion of the Treaty of Brest-Litovsk on 3 March 1918 meant the eventual evaporation of British hopes of reintegrating Russia into the Entente, although Lloyd George's government had terminated these attempts only after the uprising by the Czech troops which were to evacuate from Russia late in May that year. Meanwhile, the continuing decay of Russian rule in the eastern Baltic triggered off a rethinking of the Baltic problem by Whitehall. Slowly but surely, a more realistic understanding emerged of the impossibility of Russia preserving its Baltic provinces, and the impracticality of the autochthon peoples of the Baltic area developing under Russian rule. ${ }^{4}$ But at the same time, the British governing elite faced two great obstacles on the way to changing their approach to this region. First, most Whitehall officials, along with many MPs, regarded granting independence to ex-Imperial provinces as a repugnant precedent for the nationalist movements in British colonial possessions, such as Ireland. ${ }^{5}$ Second, they felt annoyed at French endeavours to patronise not only Poland, but also Estonia, Latvia and Lithuania

2 The Cambridge History of British Foreign Policy 1783-1919, vol. 3, eds. A. Ward, G. Gooch (Cambridge, 1923), p. 522.

${ }^{3}$ The National Archives of the United Kingdom (henceforth - TNA). Foreign Office. A.J. Balfour and Russia. Correspondence. FO/800/205. Balfour to Lindley, 21 February 1918.

${ }^{4}$ See, C. Lowe, M. Dockrill, The Mirage of Power: British Foreign Policy 1914-1922, vol. 2 (London, 1972), p. 304.

${ }^{5}$ Anderson, 'British Policy', p. 277. 
all together. ${ }^{6}$ Third, there remained the real menace of Germany filling in the power vacuum in this part of Europe. As one British diplomat remarked before the Paris Peace Conference of 1919-1920, 'We should take steps to guard against the impression spreading in the east Baltic states that the British attitude to Germany, as it has been contrasted with the French attitude, implies that Great Britain is willing to let Germany have a free hand in the Baltic States. ${ }^{7}$

On the contrary, while proclaiming the inherent right to self-determination and independence of all peoples living in the territory of the former empire, the Bolshevik leadership in reality set up Soviet regimes throughout regions populated by other nations, including Eastern Europe. The approach by various White governments to the Baltic problem may be summed up in their uncompromising refusal to grant sovereign status to local nations. Characteristically, Sergei Sazonov, a member of the Russian Political Council at the Paris Peace Conference, proposed mere administrative autonomy for them. His arguments for this initiative were typical of all patriots of the empire: granting independence to Estonia, Latvia and Lithuania would mean an inevitable threat to Petrograd as the capital city through a hypothetical foreign invasion of the Baltic coast and the interruption of Russian foreign trade through sea-ports such as Tallinn, Riga and Klaipeda. ${ }^{8}$ As Admiral Alexander Kolchak wrote in a letter to General Anton Denikin, 'The emergence of an independent Lithuania, Poland and Ukraine [...] will return Russia to the position of Muscovy after the Treaty of Stolbov [in 1617, between Russia and Sweden]. ${ }^{9}$

The end of the First World War ushered in a new epoch in the international situation. The expectations of the Baltic elites that Britain was going to replace Germany as a supporter of their national sovereignty obviously gave London's policy in the region a new dimension. As Balfour indicated in a memorandum on 18

${ }^{6}$ G. Johnson, 'Preparing for Office: Lord Curzon as Acting Foreign Secretary, January-October 1919', The Foreign Office and British Diplomacy in the Nineteenth Century, ed. G. Johnson (London-New York, 2005), p. 75.

${ }^{7}$ Quoted in: J. Simpson, 'Great Britain and the Baltic States', The Nineteenth Century and After, vol. XCIV, 560 (1923), p. 621.

${ }^{8}$ See, M. Graham, The League of Nations and the Recognition of States, vol. 3 (Berkeley, 1941), pp. 410-413; Simpson, p. 616.

${ }^{9}$ Quoted in: В. А. Зубачевский, Политика России в отнотении Восточной части Центральной Европы (1917-1923 г2.): Геополитический аспект (Омск, 2005), p. 68. Kolchak to Denikin, 5 December 1919. 
October 1918, it was apparent that Russia's recovery and return to 'normal political conditions' would take a long time. It appeared problematic, therefore, that 'these smaller nationalities' should become 'units in a federation of Russian States' instead of achieving independence themselves. The Foreign Secretary regarded sovereignty for the former Baltic provinces as the desirable termination of hostilities; while, on the other hand, he pointed to the risks that would be involved. Chief among them was the redrawing together of certain elements in both Russia and Germany demanding amendments to the territorial settlement of the Great War; and, what seemed even more ominous to the British ruling elite, the further infiltration of Bolshevism into countries lacking inner stability at that time. ${ }^{10}$

Appropriately, two more scenarios came under British consideration: the federalisation of Germany and Soviet Russia on democratic principles, and the full support by London of the states in the east Baltic region as buffers between Berlin and Moscow. Despite a kind of solidarity avowed by the leaders of the Entente in Paris, these alternatives evidently contradicted the French ambitions to reproduce an indivisible empire, and American hopes to establish a united democratic sister-republic of Russia. ${ }^{11}$

It should be noted that, apart from political motives, there was a 'hidden agenda' in the projects which the Foreign Office was elaborating at that time. Scrupulous attention should also be paid to the acknowledged importance of British capital investment, and the importance of expanding trade in the Baltic basin. Every financial analyst in the City of London became aware, as one British historian correctly remarked, that 'once these states were politically independent of the Russian hinterland, they would, therefore, surely seek greater foreign capital. ${ }^{12}$ It was in view of turning the Baltic into a 'British commercial lake', that Whitehall finally approved the ceding of the northwest provinces from Russia in its statement of 14 November $1918 .{ }^{13}$ Remarkably, Article XXV of the Compiègne

10 TNA. Cabinet papers. CAB/24/70. Memorandum by Balfour, 18 October 1918; Papers Relating to the Foreign Relations of the United States (henceforth FRUS): Russia, 1918, vol. 2 (Washington, 1931-1932), pp. 841-842.

${ }^{11}$ For a detailed analysis of the memorandum, see: Ullman, vol. 2, p. 54; Hovi, vol. 1, pp. 48-49; G. Bennett, Freeing the Baltic (Edinburgh, 2002), pp. 30-31.

12 Ullman, vol. 2, p. 55.

${ }^{13}$ Hovi, vol. 1, p. 48. 
Armistice stipulated 'freedom of access to and from the Baltic to the naval and mercantile marines of the Allies'. ${ }^{14}$

However, some members of the government in London (such as Winston Churchill) and 'men on the spot', (i.e. British commissioners, political agents and military commanders dispatched to the Baltic region), still argued for unlimited support of the Russian Northwest Army headed by Infantry General Nikolai Judenich, which was based in Estonia. Despite his opinion that 'there is no Estonia, it is a piece of Russian soil, a Russian province', the anti-Bolshevik politicians in Britain were not only eager to provide his troops with arms and war supplies, but they even agreed to keep German paramilitary units (the Freikorps) in the east Baltic area until the collapse of the Soviet regime. ${ }^{15}$

The fluctuations in diplomacy, accentuated by divergences in personal political preferences by prominent politicians such as Lloyd George, Balfour, Curzon, Long and Churchill, ${ }^{16}$ with each of them attempting to suggest to the Cabinet his own political line, resulted in ambivalent and often contradictory measures taken by Whitehall in the east Baltic. ${ }^{17}$ It is worth mentioning that Churchill and other anti-Soviet diehards were increasing pressure on the Prime Minister,

${ }^{14}$ G. Bennett, Cowan's War: The Story of British Naval Operations in the Baltic 1918-1920 (London, 1964), p. 28. On Britain's commercial interests in the region, see: J. Remer, 'The Baltic Republics: Some Revelations', The Nineteenth Century and After, vol. XLVI, 12 (1923), pp. 887-892; M.-L. Hinkkanen-Lievonen, British Enterprise and Trade in the Baltic States, 1919-1925 (Helsinki, 1984), p. 48.

${ }^{15}$ А. В. Смолин, Белое движение на Северо-Западе России, 1918-1920 г2. (Москва, 2000), pp. 81-82. On the discussions in British diplomatic and military circles about German troops in the east Baltic, esp. see: Documents on British Foreign Policy (henceforth - DBFP), 1919-1939, Ser. 1, vol. III (London, 1949), pp. 1-307. Withdrawal of German forces from the Baltic provinces, 3 July -16 December 1917.

${ }^{16}$ Lord George Nathaniel Curzon replaced Balfour as Foreign Secretary on 23 October 1919; Lord Walter Hume Long occupied the position of the First Lord of the Admiralty from January 1919 to February 1921; Sir Winston Spencer Churchill became War Secretary early in January 1919.

17 General Hubert Gough, the chief of the Allied Military Mission to the Baltic, recalled how before his departure to Helsinki late in May 1919, he was summoned to receive instructions both at the Foreign and War Office. So, while Curzon, as acting head of the former ministry, warned Gough against any acts on his own involving Britain in adventurous policies, Churchill presented arguments for a durable naval blockade of Soviet Russia alongside an attack against it by combined Finnish, Estonian and Latvian land troops, see: H. Gough, Soldiering On, Being the Memoirs of General Sir Hubert Gough (London, 1954), pp. 190-1. 
accompanied by a propaganda campaign in the mass media, in the course of the White Army's offensive against the Reds, in favour of open intervention in the Baltic. ${ }^{18}$

But as early as December 1918, the general concept of British Baltic policy began to take a more elaborated and concrete form. A memorandum by Lord Curzon stated that London ought 'to give them a chance of standing on their own feet'. ${ }^{19}$ Accordingly, on 22 May 1919, the Allied Commission on Baltic Affairs, which had been set up by the Paris Peace Conference, resolved to consider Estonia, Latvia and Lithuania as buffer states between Germany and Russia, while abstaining, nevertheless, from official recognition of their independence. ${ }^{20}$ Moreover, from the autumn of 1919, Whitehall favoured a military-political alliance of Baltic countries under the formal aegis of the League of Nations, but in reality under their indirect patronage, as a kind of bridge to fill the gap between Britain and Soviet Russia, for Lenin and Trotsky seemed more tolerant of the new independent states than the White leaders. ${ }^{21}$

It is small wonder, therefore, that some former Imperial Russian diplomats, like Konstantin Nabokov, the Chargé d'Affaires in London, expressed their disappointment at the pro-Baltic policy of the Allies: 'In words, England sympathises with us,' wrote Nabokov to one of his correspondents, 'but in practice, it encourages the sovereignty of the Baltic States to the detriment of Russian interests. While attempting to paralyse German influence, it sides with national governments, achieving the opposite result, since it provokes the indignation of Russian patriots. ${ }^{22}$

Consequently, the British government resolved to halt war supplies to the Baltic States on 24 September 1919, while simultaneously taking a neutral stance in the impending peace negotiations between them and Soviet Russia. By the end of 1919, the Admiralty had announced the withdrawal of naval forces from the east Baltic, save for a cruiser and a few destroyers. ${ }^{23} \mathrm{~A}$ month later,

18 See, for example: TNA. Cabinet Papers. CAB/29/2. Memorandum by the Admiralty on British troops landing in the Eastern Baltic, 13 January 1919.

${ }^{19}$ Quoted in: Ullman, vol. 2, p. 72.

${ }^{20}$ Anderson, p. 282.

${ }^{21}$ H. Arumäe, 'Der Diplomatische Kampf um die Schaffung des Baltischen Bundes 1919-1925', The Baltic in International relations, eds. J. Hiden, A. Loit, pp. 25-42.

22 Quoted in: Смолин, p. 301.

23 The withdrawal was accelerated by the virtual collapse of the Red Baltic Fleet, owing to the destruction of its battleships (eight sank and nine were badly 
the government determined that 'not the slightest encouragement' should be granted to the Border States to pursue a policy of war, in order to avoid responsibility which British officials would not be able to discharge. The next step in this regional appeasement was undertaken by the War Office on 3 February 1920, when Churchill announced the termination of direct military support to the White Army still occupying some outskirts of the empire. Finally, Lord Curzon instructed Colonel Stephen Tallents, the Commissioner to the Baltic provinces based in Riga, that he ought to confidentially inform the Latvian authorities of the plans under consideration by His Majesty's Government to reopen the Russian market to British commerce via sea-ports. ${ }^{24}$

In their turn, the Bolshevik leaders did their best to convince the Baltic elites that the restoration of the empire would put them back under the centralised control of Russian or German aristocratic landowners, and a corrupt bureaucracy, while Western democracies would leave them alone in the hands of former tsarist military commanders and international financial tycoons. ${ }^{25}$ After the failure of its earlier attempts to establish Soviet republics in the east Baltic region, including Finland, the Kremlin embarked on the encouragement of national movements as the only political force capable of coping with White troops recruited from Russian ex-POWs and supported by German volunteers fighting both against the Bolsheviks and the newly established Baltic States. ${ }^{26}$ That is why the Soviet leadership did not hesitate to enter into peace negotiations with national governments at the first suitable time, speeding up the conclusion of bilateral treaties of recognition, as with Estonia on 2 February, Lithuania on 12 July, and Latvia on 11 August 1920. Comparatively, we should remember that Britain abstained from official recognition of them until January 1921, and Lithuania even until December 1922. ${ }^{27}$

damaged) caused by several unexpected attacks by the British Baltic Squadron in the summer of 1919, see: A. Agar, Baltic Episode. A Classic of Secret Service in Russian Waters (London, 1963); Bennett, pp. 148-156, 239; H. Ferguson, Operation Kronstadt (London, 2008), pp. 224-256.

${ }^{24}$ DBFP, Ser. 1, vol. XI, p. 230. Curzon to Tallents, 26 February 1920.

${ }^{25}$ В. Иванович, Советский Союз и Англия в Прибалтике (Москва-Ленинград, 1927), р. 49.

${ }^{26}$ See, Dennis, pp. 102-140; Debo, pp. 85-105.

${ }^{27} \mathrm{H}$. Watson, An Account of a Mission to the Baltic States in the Year 1919 with a Record of Subsequent Events (London, 1958), p. 25 
On the other hand, any complications in the Baltic always presented a good opportunity to the Kremlin to drive a wedge between the Western Allies, particularly Britain and France. It was a small secret to Moscow that the Allies' suspicion and distrust were progressing with every month after the end of the Great War, while the initial symptoms of mutual cooling became visible to unbiased observers as early as during the Paris Peace Conference. The situation tended towards further aggravation in 1920 when the Soviet-Polish War jeopardised the very Versailles order. ${ }^{28}$

\section{The case of Lithuania in Anglo-Soviet relations}

The case of Lithuania may be regarded as a typical paragon of the challenges which London and Moscow had to meet in the culmination of the Soviet-Polish War of 1919-1921. ${ }^{29}$

After the decision of the Supreme Allied Council to lift the blockade of Soviet Russia in January 1920, Whitehall faced three problems: the menace of Bolshevism destroying the fragile stability in Europe, the revival of a united Russo-German alliance, and the weakening of the Entente because of Anglo-French friction. There also remained one more unsettled problem: the dispute between Warsaw and Moscow over the borders of eastern Poland which had not been demarcated. Hence the efforts by the Supreme Allied Council, and the British in particular, to force both Joseph Pilsudski and Vladimir Lenin to agree on the ethnic line of delimitation, or the 'Curzon Line'. ${ }^{30}$

When the Red Army seized Vilnius on 14 July 1920, and the Bolshevik government promised a subsidy of three million gold roubles to the Republic of Lithuania in exchange for the free passage of Soviet troops through its territory, London started to feverishly search for adequate counter-measures as soon as possible. A series of strong notes of protest were forwarded by Lord Curzon to Ge-

${ }^{28}$ On the impact of the Soviet-Polish War on Anglo-Russian relations, see: H. Elcock, 'Britain and the Russo-Polish Frontier, 1919-1921', The Historical Journal, vol. XII, 1 (1969), pp. 137-154; N. Davies, White Eagle, Red Star. The Polish-Soviet War, 1919-1920 (London, 1972); Debo, pp. 213-247; М. И. Мельтюхов, Сoветско-польские войны. Военно-политическое противостояние 1918-1939 г2. (Москва, 2001); Ю. В. Иванов, Очерки истории российско (советско)-польских отношений в документах. 1914-1945 годы (Москва, 2014), еtс.

${ }^{29}$ For the birth of free Lithuania, especially see: S. Page, pp. 91-97.

${ }^{30}$ Davis, pp. 167-168. 
orgii Chicherin, the head of the Peoples Commissariat for Foreign Affairs, in July 1920. The government of Lloyd George appealed to the Bolshevik government to stop further intrusion into non-Russian territory, negotiate peace terms with Polish delegates, and sign an armistice with General Petr Wrangel, whose army was occupying the Crimean Peninsula in the summer of 1920. Whitehall also suggested that the Kremlin join an international conference to be held in London under the aegis of the League of Nations in order to settle border disputes in Eastern Europe. ${ }^{31}$

Thus, on one hand, the British opposed any unwarranted Polish territorial expansion dedicated to the reestablishment of the frontiers which had existed before 1772. In this way, the coalition government sought to prevent a constant hotbed of turmoil and disturbances in the Baltic region. But on the other hand, British politicians tried to reduce the Bolshevik influence in East European countries which London regarded as its own zone of responsibility. A similar dubious policy was conducted towards two other key powers, France and Germany. While the Foreign Office disliked the strengthening of the former, it could not absolutely ignore the latter's aspiration to revanchism in the future.

Under these intricate circumstances, both the UK and Soviet Russia were bound to pay a lot of attention to democratic Lithuania, because of the key role the country played in the east Baltic as a counter-balance to Polish ambitions, a buffer state and a barrier to Bolshevik expansion to the west. It is not surprising, therefore, that London refused to recognise the sovereignty of either the LithuanianBelorussian Soviet Socialist Republic (which was abbreviated as Lit-Bel) established on 27 February 1919, or the so-called Central Lithuania, a puppet state proclaimed by General Lucjan Żeligowski on 12 October 1920, after the 'volunteer' troops under his command captured Vilnius, in spite of British opposition and the pretended disapproval of Warsaw. ${ }^{32}$

31 Документы внешней политики СССР, vol. 3 (Москва, 1959), p. 54. Curzon to Chicherin, 11 July 1920. For a thorough consideration of British diplomatic notes, see also: Davies, p. 168; Зубачевский, p. 97.

${ }^{32}$ P. Newman, Britain and the Baltic (London, 1930), pp. 123-146; P. Lossowski, Konflict polsko-litewski 1918-1920 (Warsaw, 1996); Č. Laurinavičius, 'The Baltic States between the World Wars: Foreign Policy Options and the Problem of Neutrality', Die baltischen Staaten im Schnittpunkt der Entwicklungen: Vergangenheit und Gegenwart, eds. C. Goehrke, J. von Ungarn-Sternberg (Basel, 2002), pp. 122-123. 
This led to unsuccessful British attempts to induce Lithuania to enter into a federation with Poland, on condition of getting back Vilnius as their capital city and Memel as an outlet to the sea in January $1921 .{ }^{33}$ However, Central Lithuania, comprising four districts, only ceased to exist after a plebiscite held on 8 January 1922 . This resulted in the incorporation of the Vilnius province into the territory of Poland. Both the Soviet government and the League of Nations could do nothing but officially recognise this fait accompli, although Poland and Lithuania remained at war, at least on a juridical basis, until 10 December 1927.

\section{The impact of the Baltic problem on Anglo-Soviet relations: the emergence of a Baltic Confederation}

The idea of a Baltic League originated in the plan for the establishment of a defensive alliance between Estonia and Finland. Although some historians argue that Lord Curzon suggested this scheme to an Estonian representative in London as early as the beginning of 1919, a draft proposal was announced later by Konstantin Päts, the Prime Minister of Estonia, and widely debated by Baltic intellectuals and Western analysts. ${ }^{34}$

Although the Baltic ruling elites rated different scenarios, the conferences at Helsinki and Bilduri (near Riga) agreed to take practical steps in this direction. Polish, Finnish, Estonian, Latvian and Lithuanian diplomats discussed preliminary procedures, first in January, and then in August 1920. Next, a series of further negotiations on the subject took place in Tallinn (February 1921), Helsinki (August 1921) and Warsaw (March and June 1922). ${ }^{35}$

To accelerate its progress, Whitehall used the bogey of the 'Soviet menace' in its attempts to convince the Baltic governments of the imminent Russian reconquest of their countries, as the Bolsheviks had done recently in the Trans-Caucasian region. ${ }^{36}$ In return, Mos-

${ }^{33}$ Hinkkanen-Lievonen, p. 101.

${ }^{34}$ A. Varsalanas, 'Baltic Alliance and International Politics in the First Part of the 1920's', The Baltic in International relations, eds. J. Hiden, A, Loit, p. 43. On constructing the Baltic Confederation, see: C. Sforza, Diplomatic Europe since the Treaty of Versailles (New Haven, 1928), pp. 71-73; G. Rauch, p. 96; H. Rodgers, Search for Security. A Study in Baltic Diplomacy 1920-1934 (Hamden, CT, 1975), pp. 14-24; Варес, Осипова, pp. 49-51.

35 Sforza, p. 73; Simpson, p. 620.

${ }^{36}$ DBFP, Ser. 1, vol. XXIII, pp. 54-56, record of a conversation between Sir Eyre Crowe, Permanent Under-Secretary of State for Foreign Affairs and Prince 
cow strongly criticised these activities, and attempted to thwart any combination. The ostensible substitutions for it were the bilateral treaties concluded by Soviet Russia with the Baltic States, as was mentioned above, in February and August 1920. ${ }^{37}$

However, despite a series of non-aggression pacts which they signed between themselves (except Lithuania) by the end of 1922, and a defensive treaty which Estonia and Latvia concluded in October 1923, British efforts to construct a better-organised Baltic Confederation in order to balance the Little Entente, patronised by France, proved abortive. The reasons may be described as: the insoluble controversies between potential members of the alliance, especially Poland and Lithuania: Soviet Russia and Weimar Germany's combined pressure on the states in question; the frostiness in Franco-British relations in the early 1920s; and, finally, the often unrelenting stance of the League of Nations, more moralising than resolute, in preventing political calamities. We can conclude that all these factors, taken separately as well as together, made London incapable of successfully sponsoring a kind of Baltic Benelux. ${ }^{38}$

Nevertheless, the de jure recognition of Lithuania by the Allied Supreme Council in December 1922, alongside the de facto acknowledgement of Soviet Russia as a trade partner by Western countries in 1922-1924, closed the Baltic problem, albeit for the time being without finding an appropriate solution.

\section{Conclusion}

The emergence of the east Baltic states may be called, at least partly, the product of a specific conjunction of interests between local nationalist forces and the Entente powers, which aimed at preventing a German Mitteleuropa. At the same time, while the Western Allies were doing their utmost to avoid the uncontrolled collapse and disintegration of the former multinational Russian Empire, the Bolsheviks had to compromise their ultimate goal of world revolution with the task of survival and consolidation in one country. Hence, London and Moscow became involved in a manifold diplomatic game with uncertain consequences.

Eustachy Sapieha, the Polish Foreign Minister, 2 May 1921; ibid., pp. 104-105, 164-165, correspondence between Lord Curzon and Mr Rennie, the British Minister to Finland, 17 June, 12 August 1921.

37 Варес, Осипова, pp. 51-71.

${ }^{38}$ See, Rodgers, p. 12. 
At the closing stage of the Great War, British political elites regarded the use of every possible means to defeat Germany as an objective of top priority in foreign policy. Consequently, Britain's attitude toward governments in the territory of the former Russian Empire depended on their inclination to continue war operations against the Quadruple Alliance. The requests by the east Baltic states to the Paris Peace Conference to be granted de jure recognition fell on deaf ears in London. In their turn, the Bolshevik leadership was gaining time in order to strengthen the Soviet regime and frustrate the Entente's ambitions to patronise the Baltic region.

After the Compiègne Armistice was signed in November 1918, the existence of the new independent Baltic States was at stake. Their provisional occupation by German paramilitary units in cooperation with the White Army, consisting mostly of former tsarist officers or Russian ex-POWs, alongside the invasion of these states by Bolshevik troops, compelled the Baltic governments to appeal to the Allies for diplomatic, financial and military support. ${ }^{39}$

There is evidence to sum up at least three kinds of influence on Whitehall's perception of the developments in the Baltic: first, London's fear of an imminent Soviet re-conquest of the former Imperial northwestern provinces; second, the British anticipation of an eventual revolutionary outburst in Central Europe (as occurred in Bavaria and Hungary in the spring of 1919); third, the government's desire to maintain transit maritime trade via the Baltic seaports, let alone supremacy over capital investment in weak Baltic economies. ${ }^{40}$

Accordingly, both the United Kingdom and Bolshevik Russia would use various political and economic methods, from military involvement to financial subsidies, to persuade the east Baltic states to side either with Britain or the Soviets, which became especially apparent in the culmination of the Polish-Soviet War of 1919-1921. Under these circumstances, London and Moscow opted for different scenarios: while the former embarked on the construction of the Baltic Defence Alliance, in combination with financial loans, the latter preferred to pursue a policy of bilateral pacts of mutual recognition and irrevocable monetary subsidies.

${ }^{39}$ In the Lithuanian case, there was strong evidence to believe that German paramilitary detachments infiltrated the territory of the newly independent democratic republic on their way to Soviet Russia in order to enlist in the Red Army, see: Зубачевский, p. 103.

${ }^{40}$ S. White, Britain and the Bolshevik Revolution: A Study in the Politics of Diplomacy 1920-1924 (London, 1979), p. 15. 
Despite vacillations in pursuing their Baltic policies, both Great Britain and Soviet Russia attained success in stabilizing the Border States, although only provisional. Regrettably, all these achievements proved fragile when the agreements were broken by the next international crisis in the late 1930s, when the east Baltic became an easy prey for both Stalin's Russia and Hitler's Germany.

Author Details

Evgeny Yurievich Sergeev is a doctor of history, a chief researcher at the Russian Academy of Sciences Institute of World History and a professor of modern and contemporary international history at the Russian State University for the Humanities. His fields of scholarly interest are: Russo-British relations in the 19th and 20th centuries, the diplomatic history of the First World War, the history of the British intelligence service in Russia, and international imagology.

Address: Russian Academy of Sciences Institute of World History, 32A Leninsky Prospect, Moscow, Russian Federation

E-mail: eugene.sergeev59@gmail.com

\section{Bibliography}

AGAR, A. Baltic Episode. A Classic of Secret Service in Russian Waters (London, 1963).

ANDERSON, E. 'British Policy toward the Baltic States, 1918-20', in: Journal of Central European Affairs, vol. XIX, 3 (1959), pp. 276-89.

ARUMÄE, H. 'Der Diplomatische Kampf um die Schaffung des Baltischen Bundes 1919-1925', in: The Baltic in International Relations between the Two World Wars, eds. J. Hiden, A. Loit (Upsala, 1988), pp. 25-42.

BENNETT, G. Cowan's War: The Story of British Naval Operations in the Baltic 1918-1920 (London, 1964).

BENNETT, G. Freeing the Baltic (Edinburgh, 2002).

DAVIES, N. White Eagle, Red Star. The Polish-Soviet War, 1919-1920 (London, 1972).

DEBO, R. Survival and Consolidation: The Foreign Policy of Soviet Russia 1918-1921 (Montreal, etc., 1992).

DENNIS, A. The Foreign Policy of Soviet Russia (London, 1924).

Documents on British Foreign Policy, 1919-1939, London: HMSO, Ser. 1, 1949, vol. III; 1961, vol. XI; 1980, vol. XXIII.

ELCOCK, H. 'Britain and the Russo-Polish Frontier, 1919-1921', in: The Historical Journal, vol. XII, 1 (1969), pp. 137-154.

FERGUSON, H. Operation Kronstadt (London, 2008).

GOUGH, H. Soldiering On, Being the Memoirs of General Sir Hubert Gough (London, 1954). 
GRAHAM. M. The League of Nations and the Recognition of States, vol. 3 (Berkely, 1941).

HIDEN, J., LOIT, A. (eds.), The Baltic in International Relations between the Two World Wars, (Upsala, 1988).

HINKKANEN-LIEVONEN, M.-L. British Enterprise and Trade in the Baltic States, 1919-1925 (Helsinki, 1984).

HOVI, O. The Baltic Area in British Policy 1918-1921, vol. 1 (Helsinki, 1980).

JOHNSON, G. (ed.), Locarno Revisited: European Diplomacy, 1920 1929 (London, 2004).

JOHNSON, G. 'Preparing for Office: Lord Curzon as Acting Foreign Secretary, January-October 1919', in: The Foreign Office and British Diplomacy in the Nineteenth Century, ed. G. Johnson (London-New York, 2005), p. 53-73.

KIRBY, D. The Baltic World, 1772-1993: Europe's Northern Periphery in the Age of Change (London-New York, 1995).

LAURINAVICIUS, C. 'The Baltic States between the World Wars: Foreign Policy Options and the Problem of Neutrality', in: Die baltischen Staaten im Schnittpunkt der Entwicklungen: Vergangenheit und Gegenwart, eds. C. Goehrke, J. von Ungarn-Sternberg (Basel, 2002), pp. 122-123.

LOSSOWSKI, P. Konflict polsko-litewski 1918-1920 (Warsaw, 1996).

LOWE, C., DOCKRILL, M. The Mirage of Power: British Foreign Policy 1914-1922, vol. 2 (London, 1972).

The National Archives of the United Kingdom, Cabinet Papers; Foreign Office.

NEWMAN, P. Britain and the Baltic (London, 1930).

PAGE, S. The Formation of the Baltic States. A Study of the Effects of Great Power Politics upon the Emergence of Lithuania, Latvia, and Estonia (Cambridge, 1959).

Papers Relating to the Foreign Relations of the United States: Russia, 1918, vol. 2 (Washington, 1931-1932).

RAUCH, G. Geschichte der baltischen Staaten (Stuttgart, 1970).

REMER, J. 'The Baltic Republics: Some Revelations', in: The Nineteenth Century and After, vol. XLVI, 12 (1923), pp. 887-892.

RODGERS, H. Search for Security. A Study in Baltic Diplomacy 1920-1934 (Hamden, 1975).

SFORZA, C. Diplomatic Europe since the Treaty of Versailles (New Haven, 1928).

SIMPSON, J. 'Great Britain and the Baltic States', in: The Nineteenth Century and After, vol. XCIV, 560 (1923), pp. 614-621.

STEINER, Z. The Lights that Failed: European International History 1919-1933 (Oxford, 2005).

ULlMAN, R. Anglo-Soviet Relations 1917-1921, vol. 1 (Princeton, N.J., 1961). 
VARDYS, V. S., MISIUNAS, R. J. (eds), The Baltic States in Peace and War, 1917-1945 (University Park - London, 1978).

WARD, A., GOOCH, G. (eds), The Cambridge History of British Foreign Policy 1783-1919, vol. 3 (Cambridge, 1923).

WATSON, H. An Account of a Mission to the Baltic States in the Year 1919 with a Record of Subsequent Events (London, 1958).

WHITE, S. Britain and the Bolshevik Revolution: A Study in the Politics of Diplomacy 1920-1924 (London, 1979).

Документы внешней политики СССР, т. 3: 1 июля 1920 г. - 18 марma 1921 г., ред. Г.А. Белов, Е.С. Гармаш и др. (Москва, 1959).

ИВАНОВ, Ю.В. Очерки истории российско (советско)-польских отночений в документах. 1914-1945 годы (Москва, 2014).

ИВАНОВИЧ, В. Советский Союз и Англия в Прибалтике (Москва-Ленинград, 1927).

МЕЛЬТЮХОВ М. И., Советско-польские войны. Военнополитическое противостояние 1918-1939 г2. (Москва, 2001).

НАЗАРОВА, Е.Л. (еd.), Россия и Балтия (Москва, 2002).

НАЗАРОВА, Е.Л. (ed.), Россия и Латвия в потоке истории: 2-я половина XIX - 1-я половина XX в. (Москва, 2015).

СМОЛИН, А.В. Белое движение на Северо-Западе России, 19181920 гг. (Москва, 2000).

ВАРЕС, П., ОСИПОВА, О. Похищение Европь, или, Балтийский вопрос в международных отношениях ХХ века (Tallinn, 1992).

ЗУБАЧЕВСКИЙ, В.А. Политика России в отношении Восточной части Центральной Европь (1917-1923 г2.): Геополитический аспект (Омск, 2005).

ЗУБАЧЕВСКИЙ, В.А. 'Политика России в отношении восточной части Центральной Европы. 1912-1921', in: Bonросы истории, по. 9 (2009), pp. 100-108. 


\section{ANGLŲ IR SOVIETŲ SANTYKIAI BALTIJOS PROBLEMOS \\ KONTEKSTE, 1918-1922 M.}

Santrauka

\section{EVGENY SERGEEV}

Straipsnyje apžvelgiami Didžiosios Britanijos ir Sovietų Rusijos santykių raidos etapai vadinamosios „Baltijos problemos“ kontekste, kuri tarptautinès politikos erdvèje atsirado subyrèjus Rusijos imperijai, atejus bolševikams ị valdžią ir pradèjus jiems kovoti prieš karinę „,baltujų“” opoziciją, intervencinius Antantès šalių korpusus ir naujai susikūrusių nepriklausomų valstybių kariuomenes. Autorius koncentruojasi ị dvišalių tarpvalstybinių santykių raidą, susijusią su trimis Baltijos valstybemis Estija, Latvija ir Lietuva, pastarają pasirinkdamas pagrindiniu tyrimo objektu.

Darbe keliami klausimai: kokị vaidmeni vaidino Baltijos regionas anglų ir sovietu santykiuose ankstyvaisiais pokario metais; kokie Londono ir Maskvos interesai susikirto rytinèje Baltijos regiono dalyje; kaip abiejų pusių požiūriai ị naujai iškilusị regioną (ypač Lietuvą) koregavo jų vykdomą tarptautinę politiką analizuojamu laikotarpiu; kokių rezultatų Vaitholas ir Kremlius pasiekẻ laikydamiesi savų strategijų sprendžiant „Baltijos problemas“?

I šiuos klausimus bandoma atsakyti naudojantis archyvine medžiaga, spausdintais diplomatiniais dokumentais ir įvykių liudininkų atsiminimais. Straipsnis skirstomas ị tris dalis: pirma, pristatomi ir ịvertinami britų ir Sovietų politikos motyvai rytinejje Baltijos pakrantèje; antra, analizuojama Londono ir Maskvos požiūrio i̇ Lietuvą kaita nagrinėjamu laikotarpiu; trečia, aptariama šio proceso reikšmė bandant sukurti Baltijos valstybių, įskaitant Lenkiją ir Suomiją, sajungą.

Viena pagrindinių straipsnyje pateikiamų išvadų teigia, kad galima pastebèti Didžiosios Britanijos politikos pokyčius Baltijos valstybių atžvilgiu: nuo savivaldos statuso propagavimo iki visiškos jų nepriklausomybès pripažinimo. Tokią politiką rèmė ir Sovietų valdžia, tačiau tuo pat metu ji aktyviai priešinosi Didžiosios Britanijos proteguojamos ir Tautų Lygos palaikomos Baltijos lygos (arba Federacijos) atsiradimui regione. 